\title{
Sunset Over Hand-Made Church .
}

\section{Jane Miller}

Like,

people get emotionally tied to

the first person who

fucks them up

the ass,

god willing,

we were driving toward Biarritz

\& stopped to call Alexis,

exhilaration in our voices

as we described the scenery, an emotion

akin to Carlos Williams'

man swinging a shirt over his head

or Hass' shouting hello

to an empty house,

$\&$ as

the one pleasure of the traveler

holding a lemon to his nose on a windless day

is to know he can leave,

the week we saw Arles

we enlarged everything

out of our minds,

Arles exactly as painted by Van Gogh,

the goldenrod, wheat, apple trees,

no one

tending them in all the hours we drove,

for the French, odd,

not a soul, 
the difference being

we had each other \& were still

believing in a god,

menage a trois, the next day slept between mountains

where the proprietor caught trout

$\&$ we ate in the poised and spirited

style of women alone

among men in the immaculate

dining room,

like a picture of a country dining room serving rose pears.

What a night in a featherbed

in a room with a high ceiling, life has been good, good, finding our empty purse $\&$ providing the wine we drink under a quilt.

I did not want anyone to see that my face was so happy,

because I had slipped into the face of my dead, who know so precisely what to relive with their heads calmed like a unicorn in the lap of a virgin,

\& through me drive through

France

with you, this gentle self Jane who

buys a paper $\&$ crosses the square for a beer

in Tourrette-sur-Loup, scaling the terraces of the olive trees after lunch

to play the wooden flute.

It's this distance from you,

this freedom we have to forgive,

that keeps us on a tether

like goats, exactly like

ghosts. 